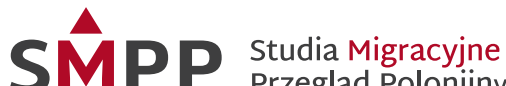 Przegląd Polonijny
}

Migration Studies - Review of Polish Diaspora nr 2 (176)/2020, http://www.ejournals.eu/Studia-Migracyjne/ DOI: 10.4467/25444972SMPP.20.014.12330

\section{Nowe media a rekonstrukcja kapitału społecznego migrantów ukraińskich na polskim rynku pracy}

\author{
SYLWIA GALANCIAK ${ }^{1}$ \\ ORCID: 0000-0002-9850-3954 \\ Akademia Pedagogiki Specjalnej im. Marii Grzegorzewskiej w Warszawie \\ BOHDANA HURIY \\ ORCID: 0000-0002-0855-4556 \\ Akademia Ignatianum
}

Od wybuchu w 2014 roku wojny rosyjsko-ukraińskiej i związanego z nią kryzysu polityczno-ekonomicznego Polska pozostaje głównym kierunkiem migracji obywateli Ukrainy (OECD 2018, Jaroszewicz 2018). Nowi imigranci przybywają ze zróżnicowanym przygotowaniem w zakresie językowym, prawnym czy społecznym (NBP 2018). Tymczasem badania relacji pomiędzy kapitałem niematerialnym obywateli a rozwojem gospodarki wskazują na znaczącą rolę kapitału społecznego i kulturowego w budowaniu stabilnie rozwijającej się gospodarki (Czapiński 2008). Artykuł prezentuje wyniki prowadzonych w 2019 roku badań dotyczących identyfikacji eksponowanych w Internecie informacyjnych potrzeb ukraińskich migrantów szukających zatrudnienia w Polsce. Analiza postów Ukraińców w sieci społecznościowej Facebook oraz częściowo ustrukturyzowanych, pogłębionych wywiadów eksperckich, pozwoliła wyłonić zestaw pięciu kategorii informacji, jakich imigranci poszukują w Internecie (związanych z przepisami prawnymi i dokumentami, z pracą, miejscem zamieszkania i zakwaterowaniem, dostępem do usług oraz wypoczynkiem i formami spędzania czasu wolnego) oraz wskazać media społecznościowe jako ważne narzędzie redukcji deficytu kapitału społecznego, z którym borykają się migranci w kraju przyjmującym.

Słowa kluczowe: imigranci, Ukraina, polski rynek pracy, kapitał społeczny, media społecznościowe, e-learning.

\footnotetext{
1 Kontakt: bohdana.huriy@ignatianum.edu.pl
} 


\section{New Media and the Reconstruction of Ukrainian Migrants' Social Capital on the Polish Labour Market}

Since the outbreak of the Russian-Ukrainian war in 2014 and political and economic crisis caused by that situation, Poland has remained the main direction of Ukrainian citizens' migration (OECD 2018, Jaroszewicz 2018). New immigrants arrive with varied linguistic, legal and social preparation (NBP 2018). Meanwhile, studies of the relationship between the intangible capital of citizens and the development of the economy clearly show the significant role of social and cultural capital in building a steadily developing economy (Czapiński 2008). The work presents the results of research conducted in 2019 on the needs of Ukrainian migrants seeking employment in Poland. An analysis of the content of Ukrainians' posts on social network platform Facebook and partially structured, in-depth expert interviews have resulted in the construction of a set of five categories of information that immigrants are looking for on the Internet (legal provision and documents, work, place of residence and accommodation, access to services as well as leisure and leisure activities). The study has also identified social media as an important tool of reducing the social capital deficit affecting migrants in the host country.

Keywords: immigrants, Ukraine, Polish labour market, social capital, social media, e-learning

\section{Wprowadzenie}

Przemiany zachodzące w globalnej gospodarce, silnie powiązane z rozwojem technologii cyfrowej, przynoszą wiele zmian także w codziennym życiu ludzi (Bauman 2000, 2006b, Beck 2006, Castells 2003, Giddens 2008, van Dijk 2010). Każdego dnia nowe technologie oddziałują na sposoby sprawowania władzy, prowadzenia biznesu, organizację pracy, relacje interpersonalne czy wreszcie sposoby uczenia się. Choć realizacja dydaktycznego potencjału nowych mediów, rozumianych tu jako „zintegrowane i interaktywne media przełomu XX i XXI wieku oparte na kodzie binarnym" (van Dijk 2010, s. 20; zob. też Manovich 2011, Levinson 2010), zdaje się odbiegać od oczekiwań, niewątpliwie należy podkreślić ich zdolność do równoważenia barier związanych z pokonywaniem czasoprzestrzennych ograniczeń dostępu do wiedzy czy rozumieniem różnic kulturowych (możliwość zdalnego kontaktu z kulturą kraju przed przybyciem do niego). W zglobalizowanym świecie niezbędną cechą edukacji, rozumianej jako „ogół wpływów na jednostki i grupy ludzkie, sprzyjających takiemu ich rozwojowi, aby w najwyższym stopniu stały się one świadomymi i twórczymi członkami wspólnoty społecznej, kulturowej i narodowej..." (Kwieciński 1991: 89), staje się indywidualizacja uczenia się, orientowanego na przeżywanie doświadczeń i samodzielne zdobywanie wiedzy. Jest to szczególnie ważne w kontekście nasilania się zjawiska migracji zarobkowych, gdzie od dobrego przygotowania migranta do życia w kraju przyjmującym zależy zarówno jego sukces, jak i dobrostan państwa, które go przyjęło. Internet i media cyfrowe coraz częściej stanowią w tej sytuacji ważne źródło wiedzy: dla imigranta - o warunkach życia w nowej dla niego kulturze, zaś dla kraju przyjmującego - na temat wielu istotnych potrzeb osoby migrującej. Media te 


\section{SM̂PP}

ułatwiają więc, a często wręcz umożliwiają obu stronom (od)budowę kapitału społecznego, którego zasoby warunkują sukces integracji na nowych, szerszych podstawach. Świadczą o tym zarówno wyniki badań dotyczących aktywności imigrantów w sieci, jak i sam fakt ich prowadzenia (por. Spyratos, Vespe, Natale, Ingmar, Zagheni, \& Rango 2018; Leonowicz-Bukała 2013; Siuda 2008; Hiller, Franz 2004; Navarette, Huerta 2006; Nedelcu 2012; Dekker, Engbersen 2014 i in.).

Głównym celem prezentowanych w artykule badań, przeprowadzonych w pierwszej połowie 2019 roku w ramach Programu Stypendialnego Lane'a Kirklanda, była identyfikacja wątków tematycznych najczęściej występujących w pytaniach zadawanych przez ukraińskich imigrantów w serwisie społecznościowym Facebook. Poczynione na tej podstawie ustalenia poszerzono następnie o wyniki analizy treści pięciu wywiadów eksperckich, przeprowadzonych z ekspatami (por. Spyratos, Vespe, Natale, Ingmar, Zagheni, \& Rango 2018) wykorzystującymi portale społecznościowe do prowadzenia działalności integracyjno-kulturalnej, a także związanej z doradztwem zawodowym i rekrutingiem dla imigrantów. Były to osoby silnie zaangażowane w działania adaptacyjne skierowane do środowiska migrantów z Ukrainy. Wyłonione w toku analizy wątki powiązano z procesem odbudowywania kapitału społecznego, który na skutek migracji może w znacznym stopniu ulec destrukcji. Kolejnym celem była analiza roli, jaką media społecznościowe i Internet odgrywają w procesie rekonstrukcji kapitału społecznego ukraińskich imigrantów w nowym miejscu pobytu.

Wypowiedzi ekspertów pozwoliły przyjrzeć się barierom, na jakie napotykają w Polsce migranci i zastanowić, które z nich mogą ulec redukcji dzięki mediom społecznościowym. Media te stanowią potencjalne źródło wiedzy na temat kraju przyjmującego, a także platformę nawiązywania nowych kontaktów i podtrzymywania dawnych, z miejsca pochodzenia. Tym samym intensywnie wspierają proces rekonstrukcji kapitału społecznego, którego wysoki poziom jest niezbędny do skutecznej integracji społecznej (Sztompka 2016: 326-327; Milerski, Ruszczak-Żbikowska 2008). Rola tego typu kapitału jest szczególnie istotna w sytuacji, w której społeczeństwo kraju przyjmującego migranta samo wykazuje deficyty w tym obszarze (niski poziom zaufania, niechęć do obcych, nieangażowanie się w sprawy społeczności etc.). Sytuacja taka utrudnia osobie nowo przybyłej odbudowanie utraconych zasobów. Na znaczeniu zyskują wówczas wszelkie dodatkowe formy wsparcia migranta w procesie rekonstrukcji kapitału, pośród których istotną rolę odgrywają media społecznościowe.

\section{Kapitał społeczny migranta a szansa na sukces migracyjny}

Mobilność ludzi, którą socjologowie jednomyślnie uznają za cechę dystynktywną epoki ponowoczesnej (zob. Bauman 2000, 2006; Beck 2006; Giddens 2004), a której jedną z najważniejszych form jest migracja (zob. Górny, Kaczmarczyk 2003; Grabowska-Lusińska, Jaźwińska 2012), realizuje się w praktyce społecznej w dwóch 
podstawowych wymiarach: jako mobilność terytorialna, utożsamiana z gotowością zmiany miejsca zamieszkania, a także jako mobilność zawodowa, związana z elastycznością w kształtowaniu własnej ścieżki zawodowej i zdolnością zdobywania nowych umiejętności dostosowanych do aktualnych potrzeb rynku pracy. W przypadku zjawiska migracji zarobkowej często zachodzi konieczność połączenia obu typów mobilności (Kaczmarczyk, Tyrowicz 2008), tym trudniejszego, że zmiana obejmuje też funkcjonowanie w innym systemie prawnym i administracyjnym, a także w innej rzeczywistości językowej i kulturowej. Stawia to imigranta w wyjątkowo trudnej sytuacji nie tylko zawodowej, ale i psychologicznej oraz społecznej, co z kolei może utrudnić mu wejście na rynek pracy i odnalezienie się w realiach życia w obcym państwie (np. praca poniżej kwalifikacji, por. Kaczmarczyk, Tyrowicz 2008: 9-10). Następuje bowiem istotna redukcja kapitału niematerialnego, jakim dysponuje.

Kapitał to w ekonomii wszelkie zasoby posiadające jakąś wartość, które, wprowadzone w obieg, pomnażają ją lub służą pozyskiwaniu innych zasobów (Sztompka 2016: 282-286; Czapiński 2008: 5-9). Nauki społeczne poszerzyły jednak tę kategorię o spostrzeżenie, że oprócz zasobów materialnych i finansowych człowiek dysponuje dobrami niematerialnymi, które w silny sposób oddziałują na jego sytuację ekonomiczną i społeczną. W konsekwencji zaczęto mówić o kapitale ludzkim obejmującym zasoby intelektualne, motywacyjne i symboliczne człowieka, takie jak zdolności, wykształcenie, doświadczenie zawodowe, pozycja społeczna oraz dobrostan fizyczny i psychiczny oraz o kapitale społecznym, rozumianym jako sieć wzajemnych relacji jednostki i innych członków grupy - zaufanie, gotowość do działania dla dobra wspólnego, dobrowolna przynależność do organizacji, szacunek czy lojalność (Putnam 2003, Czapiński 2008, Sztompka 2016). Trudno ocenić, który z niematerialnych typów kapitału jest najistotniejszy dla dobrostanu człowieka, jednak prace wymienionych badaczy wskazują na to, iż deficyty w obszarze któregoś z nich znacząco utrudniają, a często uniemożliwiają jednostce osiągnięcie sukcesu, realizację potencjału czy poprawienie pozycji w hierarchii społecznej.

Każdy migrant boryka się z trudnościami związanymi z utratą znacznych części zasobów tworzących jego własny kapitał niematerialny, takich jak umiejętności językowe, nierzadko wykształcenie, które poza granicami traci ważność, sieć kontaktów społecznych, prestiż społeczny, możliwość uczestniczenia w życiu publicznym. Do tego dochodzi deficyt jednej z podstawowych składowych kapitału społecznego zaufania imigranta do grupy przyjmującej i na odwrót. Jak zauważa Piotr Sztompka, zmiana miejsca zamieszkania (nawet w obrębie tego samego kraju) to jeden z podstawowych czynników powodujących atrofię i rozpad kapitału społecznego człowieka. Różnorodność i istotność potrzeb, jakie kapitał ten zaspokaja, motywują go jednak do podjęcia wysiłku jego rekonstrukcji w nowych okolicznościach i na nowych warunkach (Sztompka 2016: 326-327; Milerski, Ruszczak-Żbikowska 2008). W przypadku imigrantów owa zmiana miejsca zamieszkania zawsze powszechnie łączyła się ze 156 zmianą ich miejsca w hierarchii społecznej i zawodowej, na pierwszym etapie migracji 


\section{SM̂PP}

zwykle na gorsze, zaś poprawa uwarunkowana była w znacznym stopniu zdolnością integracji z nowym społeczeństwem (por. Znaniecki 1976; Grabowska, Jaźwińska 2012; Chiswick, Lee 2005). W przypadku klasycznej migracji zarobkowej, z dominującą grupą pracowników najemnych do najprostszych robót, kapitał społeczny może nie mieć większego znaczenia, natomiast dla imigracji o wyższych ambicjach ma już duże. Jak twierdzi Czapiński (2008: 20), „im wyższy jest poziom wykształcenia, tym większy jest pozytywny efekt kapitału społecznego w zakresie indywidualnego statusu materialnego". W badaniach porównawczych kapitału społecznego Polaków i mieszkańców innych krajów europejskich wykazał on, że

gęsta sieć relacji społecznych i otwarty stosunek do ludzi spoza własnej grupy nie zwiększają zapewne zarobków osób wykonujących proste, rutynowe prace (...). W zgoła innej natomiast sytuacji znajdują się osoby mobilne zawodowo, poruszające się po długiej ścieżce awansu pionowego, wykonujące zadania, które wymagają twórczej współpracy z innymi pracownikami i z otoczeniem firmy (Czapiński 2008: 17-18).

W przypadku zjawiska migracji jest to grupa, na której przyciągnięciu i zatrzymaniu szczególnie zależy krajowi przyjmującemu - wysoko wykwalifikowanych pracowników, którzy szczególnie przyczyniają się do rozwoju gospodarki. Równocześnie jest to grupa, której sukces zależy w dużym stopniu od możliwości szybkiego odbudowania strat kapitału ludzkiego (np. odzyskanie uprawnień zawodowych) i społecznego (Jóźwiak, Piechowska 2017; Grabowska-Lusińska, Jaźwińska 2012). Ta ostatnia zależy zaś także od postaw, jakie wobec imigrantów prezentuje społeczeństwo kraju przyjmującego.

\section{Internet jako źródło informacji dla i o migracji}

Negatywne postawy mieszkańców kraju przyjmującego mogą niekorzystnie wpłynąć na proces odtwarzania kapitału imigranta, jednak - jak wskazują badacze (Jóźwiak, Piechowska 2017; Grabowska-Lusińska, Jaźwińska 2012) - istnieją czynniki, które pomagają skutecznie niwelować problemy związane z migracją - wysokie kompetencje zawodowe w połączeniu z umiejętnością korzystania z nowych mediów. Jak podkreśla Leonowicz-Bukała (2013: 58), rola, jaką Internet odgrywa w życiu współczesnego migranta, jest bezprecedensowa. Przede wszystkim w dobie dynamicznego rozwoju mediów społecznościowych (Facebook, Skype, Instagram, Twitter) stają się one dla migrantów jednym z ważnych źródeł informacji na temat kraju przyjmującego (Spyratos, Vespe, Natale, Ingmar, Zagheni, \& Rango 2018; Leonowicz-Bukała 2013; Hiller, Franz 2004; Navarette, Huerta 2006; Nedelcu 2012; Dekker, Engbersen 2014). To przestrzeń wymiany wiadomości oficjalnych, pochodzących od instytucji i nadzieja na pozyskanie informacji nieformalnych, zdobycie kontaktów i zadanie pytań imigrantom, którzy zdążyli się już zadomowić w nowym kraju (nadzieje te bywają płonne, 
jak pokazują badania Marty Kindler i Katarzyny Wójcikowskiej-Baniak, środowisko imigrantów jest do pewnego stopnia podzielone, a imigranci „osiadli” postrzegają nowo przybyłych jak konkurencję na rynku pracy - por. Kindler, Wójcikowska-Baniak 2019). Kompetencje medialne stają się tym samym jedną z kluczowych składowych kapitału osoby nowo przybyłej do kraju przyjmującego. Ponadto istnienie mediów społecznościowych w pewnym sensie uniezależnia internautę od miejsca pobytu, pozwalając na zachowanie kontaktu z rodziną i rodzimą społecznością, na stworzenie „wirtualnego mostu łączącego z domem” (Navarette, Huerta 2006). Pomaga także imigrantom w tworzeniu między nimi samymi więzi opartych na poczuciu wspólnoty związanej z miejscem pochodzenia (Hiller, Franz 2004; Siuda 2008; Leonowicz-Bukała 2013). Na skutek zacierania się granic czasu i przestrzeni, w efekcie możliwości pracy zdalnej i zdalnej komunikacji z bliskimi, wykształca się, jak twierdzi M. Nedelcu, nowa, transnarodowa forma społecznej egzystencji, czyniąca z e-migranta obywatela świata (Nedelcu 2012: 1340).

Ze względu na powyższe okoliczności, badacze zajmujący się problematyką migracyjną próbują wykorzystywać bazy danych użytkowników portali społecznościowych do szacowania skali migracji, także tej wymykającej się statystykom (Spyratos, Vespe, Natale, Ingmar, Zagheni, \& Rango 2018), prowadzą netnograficzne badania jakościowe, analizując treści pozostawione w sieci przez internautów (Nedelcu 2012), czy wreszcie wykorzystują Internet do rozpowszechniania ankiet wśród badanych grup migrantów. Jak wskazują wyniki badań netnograficznych, sama treść postów zamieszczanych w mediach społecznościowych może więc stanowić ważne źródło wiedzy na temat imigrantów. Dla potrzeb badania opisanego w niniejszym opracowaniu sięgnięto do takich właśnie danych, jednak zanim zostaną one przedstawione, warto przyjrzeć się szerzej sytuacji migracji ukraińskiej w Polsce.

\section{Ukraińscy imigranci na polskim rynku pracy}

Na skutek przeciągającego się kryzysu związanego z konfliktem zbrojnym z Rosją, rynek pracy na Ukrainie stanowi jedno z najsłabszych ogniw gospodarki tego państwa. Przedsiębiorcy skarżą się na brak wykwalifikowanych pracowników, a równocześnie stopa bezrobocia rośnie (13,7\% w I kwartale 2020 r.). Jednak największym problemem pozostaje wysokość wynagrodzeń za pracę (w tym brak wynagrodzeń) oraz brak równowagi między proponowanym i oczekiwanym wynagrodzeniem. Czynnik ten, obok toczącego się wciąż na wschodzie kraju konfliktu z Rosją, sprawia, iż dramatycznie wzrasta wskaźnik migracji. Przykładowo liczba Ukraińców wyjeżdżających z kraju w celu poszukiwania pracy tylko w latach 2015-2017, rekordowych ze względu na eskalację konfliktu z Rosją, wyniosła ok. 1,3 miliona osób. Migrowano w szczególności do Polski (507 tys. osób), Rosji (343 tys.), Włoch (147 tys.), Czech

158 (122 tys.), USA (23 tys.) i Białorusi (22 tys.) (Piontkivska, Jablonovsky, Ruda 2018; 


\section{SM̂PP}

Urząd do Spraw Cudzoziemców 2019; Jaroszewicz 2018). Jednym z najbardziej dotkliwych problemów kraju staje się w związku z tym brak wykwalifikowanej kadry. Także studenci wyjeżdżają z Ukrainy na studia za granicą, a większość z nich nie wraca. Według Centrum Analitycznego CEDOS w latach 2016-17 opuściły kraj 72000 młodych ludzi - to o 56\% więcej niż w okresie 2012-13. Z kolei według badań z 2017 roku przeprowadzonych przez Tetyanę Pashkiną, eksperta ds. HR z portalu Rabota.ua, 9 z 10 studiujących za granicą nie planowało powrotu na Ukrainę. Jedną z przyczyn takiego stanu rzeczy są z pewnością zarobki - średnia pensja w krajach europejskich wynosiła w roku 2017 trzykrotność średniej pensji ukraińskiej (Пашкіна 2017) i sytuacja ta nie ulega widocznej poprawie. Ze względu na dynamikę wzrostu płac zagraniczni pracodawcy od kilku lat chętnie zatrudniają ukraińskich pracowników zadowalających się niższymi, lecz dla nich i tak wysokimi zarobkami (Пашкіна 2017). Realna skala migracji jest prawdopodobnie o wiele większa niż ta, i tak już wysoka, prezentowana w oficjalnych dokumentach, ze względu na fakt, iż Państwowa Służba Statystyki Ukrainy od 2014 r. nie rejestruje danych dotyczących Autonomicznej Republiki Krymu i miasta Sewastopol oraz terytoriów, które nie znajdują się pod kontrolą władz ukraińskich. Według badań przeprowadzonych pod koniec 2017 r. przez Kijowski Międzynarodowy Instytut Socjologii, prawie co trzeci obywatel Ukrainy myślał o emigracji ze względu na niski poziom dochodów (Мостова, Рахманін 2018).

Na specyfikę migracji obywateli ukraińskich po 2014 roku nakładają się jednak także wszechobecne procesy globalizacyjne. Mobilność ludzi wzrasta i coraz częściej nie ma charakteru stabilnego. Jest chwilową strategią życiową, sposobem budowania kariery, epizodem w CV (Grabowska, Jaźwińska 2012). Otwieranie granic międzypaństwowych na przybyszów z innych krajów, bezproblemowość przemieszczania się czy wreszcie niezwykła łatwość komunikowania się za pomocą mediów cyfrowych na ogromne odległości w czasie rzeczywistym - wszystko to sprawia, że coraz więcej ludzi decyduje się na migrację. Społeczność ukraińskich imigrantów przybywających do Polski w celach zarobkowych w dużym stopniu składa się z przedstawicieli tzW. generacji Y (a nawet jeszcze młodszej, Z, urodzonej po 2000 roku) - obytej z nowymi technologiami, dobrze wykształconej, świadomej własnych potrzeb i wytrwałej w ich realizacji. Wśród osób, które ogółem opuściły Ukrainę w celach zarobkowych w latach 2014-18, 41\% miało mniej niż 35 lat, a tylko 20\% migrantów zarobkowych były to osoby w wieku powyżej 60 lat (Лібанова 2018). Spośród nich wielu trafiło do Polski. Ci młodzi to imigranci nowego typu - obywatele świata, nierzadko traktujący kraj, do którego przybyli jako przystanek w podróży. Nie są zainteresowani zdobyciem jakiejkolwiek pracy, ale, świadomi własnych zalet i mocnych stron, konsekwentną budową kariery zawodowej oraz wysoką jakością życia prywatnego.

Ciągły kontakt z bliskimi dzięki mediom społecznościowym, możliwość nawiązania relacji w kraju przyjmującym jeszcze przed wyjazdem z ojczyzny, podobieństwo języków ułatwiające naukę polskiego - wszystko to sprawia, że w przypadku młodych 
ukraińskich imigrantów w Polsce typowe dla imigracji straty w obszarze kapitału niematerialnego nie są tak dotkliwe, jak dla pokolenia ich rodziców. Nie znaczy to jednak, że ich nie ma. Przybysze z Ukrainy precyzyjnie określają swoje potrzeby, a jako że są to osoby, na których zatrzymaniu na dłużej powinno szczególnie zależeć polskiej gospodarce cierpiącej na deficyt pracowników (zwłaszcza w sektorach związanych z przemysłem i handlem, gdzie poszukuje się robotników i rzemieślników, monterów i operatorów maszyn, handlowców, ale także specjalistów - por. GUS 2019: 3), warto te potrzeby zdiagnozować i wyjść im naprzeciw, umożliwiając podjęcie pracy odpowiadającej poziomowi kwalifikacji. Koncentracja uwagi na najlepiej sobie radzących imigrantach z pokolenia cyfrowych tubylców stanowiłaby jednak przekłamanie obrazu migracji ukraińskiej. Struktura tej migracji jest bowiem zróżnicowana i obok młodych, wykształconych przybyszów, którzy ściągają przede wszystkim do dużych miast (zwłaszcza Warszawy), składa się z osób z niższym wykształceniem i o mniejszych kompetencjach (także medialnych), wykonujących prace niewymagające wysokich kwalifikacji, których część szuka zatrudnienia poza wielkimi ośrodkami (Urząd do Spraw Cudzoziemców 2019).

Do momentu wybuchu wojny z Rosją do Polski przybywali przede wszystkim migranci zarobkowi z Zachodniej Ukrainy, często podejmując sezonowe prace w gospodarce rolnej i planując powrót do domu między sezonami. Raport o pracy Ukraińców w Polsce opublikowany przez Narodowy Bank Polski (NBP) w 2016 roku wskazał jednak, że ta sytuacja uległa zmianie. Konflikt we Wschodniej Ukrainie uruchomił nową falę migracji. Ponad 40\% badanych Ukraińców w 2015 roku deklarowało, że pierwszy raz pracują w Polsce. Byli oni młodsi od swoich poprzedników - średnia ich wieku to 33 lata, o dziesięć lat mniej niż wśród bardziej doświadczonych imigrantów. Ponadto o ile w 2013 roku tylko 6\% Ukraińców pracujących w Polsce pochodziło ze Wschodniej i Południowej Ukrainy, po 2014 roku ten wskaźnik wzrósł do 28\% (Chapman 2018).

Mimo że na Ukrainie występują coraz większe deficyty kadrowe również po stronie zawodów specjalistycznych, 2/3 przebadanych Ukraińców świadczy w Polsce pracę poniżej swoich kwalifikacji. W największym stopniu dotyczy to osób z wyższym wykształceniem, wśród których odsetek takich deklaracji sięga aż 81\%. Według danych Urzędu do Spraw Cudzoziemców w latach 2014-2019 wniosek o udzielenie zezwolenia na pobyt czasowy złożyło 614441 osób, w tym 441853 jako cel pobytu wskazało pracę, 57706 - dołączenie do rodziny, 49694 studia, a 65188 wskazało inne powody. W tym samym czasie 47132 osoby złożyły wnioski o zezwolenie na pobyt stały (Urząd do Spraw Cudzoziemców 2019).

Według danych Polskiej Fundacji Edukacji „Perspektywy” w roku 2017 na polskich uczelniach studiowało 23,3 tysiąca Ukraińców, co stanowiło o 8 tysięcy więcej niż w roku poprzednim (Кулицький 2017). Badania Międzynarodowego Instytutu Edukacji, Kultury i Współpracy z Diasporą z 2018 roku wykazały, że 90\% badanych 160 studentów chciało emigrować za granicę, z czego jedna trzecia z nich - do Polski 


\section{SM̂PP}

(Випускники 2018). Dane te dotyczą deklaracji, które nie muszą przekładać się na rzeczywistość, są jednak sygnałem stosunku młodych Ukraińców, aspirujących do wyższego wykształcenia, do perspektyw, jakie oferuje im kraj i zagranica.

\section{Informacje poszukiwane w mediach społecznościowych przez ukraińskich imigrantów w Polsce - założenia metodologiczne badań}

Badania podzielono na dwa etapy - w pierwszym dokonano ilościowej i jakościowej analizy zawartości wątków zakładanych przez ukraińskich migrantów w Polsce w najpopularniejszym portalu społecznościowym Facebook (ponad 75\% wszystkich użytkowników mediów społecznościowych w Europie w 2018 roku, w okresie objętym badaniem; Lepiej Widoczni 2020), zaś w drugim przeprowadzono częściowo ustrukturyzowane, pogłębione wywiady eksperckie, do których sformułowano pytania na podstawie wyników etapu pierwszego. Pierwszy etap badań miał miejsce od września 2018 roku do marca 2019 roku. Analizie poddano wpisy ukraińskich migrantów dokonywane w okresie od stycznia 2018 - do marca 2019 na pięciu stronach (wątkach tematycznych) założonych w sieci społecznościowej Facebook, popularnych wśród Ukraińców przebywających w Polsce i podejmujących tematykę dotyczącą ich sytuacji prawnej, społecznej, zawodowej i ekonomicznej. Spośród analizowanych stron, których nazwy zostały dla potrzeb niniejszego artykułu zanonimizowane w celu ochrony użytkowników, trzy były skierowane do osób mieszkających głównie w Warszawie oraz województwie mazowieckim (ponad 21\% wszystkich Ukraińców zgłoszonych do ubezpieczenia w Polsce wg danych ZUS 2019) i liczyły: Strona A - 11670 użytkowników, Strona B - 7998, Strona C- 11669 użytkowników. Dwie pozostałe strony przeznaczone były dla migrantów mieszkających w całej Polsce: strona D liczyła 32055 użytkowników, a strona E - 1995). W przypadku częściowo ustrukturyzowanych wywiadów pogłębionych, badaniem objęto 5 ekspertów mieszkających w Warszawie, ale obejmujących działalnością całą Polskę. Wszyscy byli obywatelami Ukrainy mieszkającymi w Polsce nie mniej niż 3 lata, znającymi środowisko ukraińskich imigrantów. Wybór na nich padł ze względu na fakt, iż są oni zawodowo zaangażowani w działania wspierające ukraińskich migrantów na polskim rynku pracy i wykorzystują w tym celu media społecznościowe. Przeprowadzenie analizy zawartości stron pozwoliło na wyodrębnienie potrzeb informacyjnych warunkujących według migrantów udaną adaptację do warunków kraju przyjmującego i możliwość samorealizacji na rynku pracy w Polsce. Badanie dodatkowe, przeprowadzone za pomocą wywiadów, miało na celu pogłębienie problematyki funkcjonowania Ukraińców na polskim rynku pracy, lepsze zrozumienie procesów, które odbywają się w tym obszarze, a także podjęcie dyskusji na temat roli nowych mediów w odbudowywaniu zasobów społecznych migrantów. 


\section{Analiza wyników badań}

Wyniki analizy informacji zawartych na badanych stronach pozwoliły na zidentyfikowanie 5 typów informacji, jakich ukraińscy migranci w Polsce poszukują w Internecie. Dotyczą one: 1) dokumentów i przepisów prawnych, 2) zakwaterowania, 3) poszukiwania pracy, 4) usług, 5) rozrywki i odpoczynku. Szczegółowe informacje zwiera tabela 1. Zauważalne jest zróżnicowanie tematyczne poszczególnych stron, w zależności od ich grupy docelowej (internauci poszukujący uniwersalnych informacji na temat kraju przyjmującego, jego przepisów prawnych etc., lub ci, którzy poszukują wiadomości lokalnych, związanych z miastem/regionem, do którego przybywają). Strony warszawskie (Strony 1, 2 i 3), ze względu na charakter regionalny, zawierają więcej tematów szczegółowych dotyczących konkretów związanych z organizacją życia w nowym kraju i mieście (dokumenty i przepisy, zatrudnienie - tu zwłaszcza specjalizująca się w problematyce pracy strona C). Odmiennych informacji poszukują użytkownicy stron ogólnopolskich, gdzie zdecydowanie dominują wątki związane z kulturą, rozrywką i czasem wolnym, służą więc w większym stopniu poznaniu kraju przyjmującego, któremu można poświęcić czas po zorganizowaniu życia w wymiarze lokalnym.

Tabela 1

Kwestie poruszane przez ukraińskich imigrantów na stronach Facebook w okresie luty-maj 2019 roku (w \%)

\begin{tabular}{|c|c|c|c|c|c|}
\hline Portal & $\begin{array}{c}\text { Dokumenty } \\
\text { i przepisy }\end{array}$ & $\begin{array}{c}\text { Zakwatero- } \\
\text { wanie }\end{array}$ & $\begin{array}{c}\text { Poszuki- } \\
\text { wanie } \\
\text { pracy }\end{array}$ & Usługi & $\begin{array}{c}\text { Rozrywka } \\
\text { i odpoczynek }\end{array}$ \\
\hline Strona A & 30 & 20 & 10 & 30 & 10 \\
\hline Strona B & 60 & - & 5 & 10 & 25 \\
\hline Strona C & 5 & 20 & 60 & 10 & 5 \\
\hline Strona D & 5 & 5 & 15 & 15 & 60 \\
\hline Strona E & 5 & 15 & 15 & 5 & 60 \\
\hline
\end{tabular}

Źródło: opracowanie własne

Grupą bardziej aktywną w publikowaniu postów na badanych stronach są kobiety (58\%), zarówno jako autorki pytań, jak i odpowiedzi. Zjawisko to koresponduje z wynikami badań użytkowników Facebooka na terenie Polski (w październiku 2019 roku pośród 18350000 użytkowników serwisu 53\% stanowiły kobiety - WhySocial 2019). Tematyka najczęściej przez nie poruszana dotyczy pracy, usług, a także organizacji czasu wolnego. Mężczyźni najczęściej piszą na temat pracy i usług, w dalszej 


\section{SM̂PP}

kolejności poruszane są kwestie dokumentów i przepisów, a także zakwaterowania. Aktywność publikacyjna internautów regularnie zwiększa się pod koniec tygodnia. Pytania z największą liczbą odpowiedzi dotyczą dokumentów, procesów prawnych, interpretacji przepisów związanych z procesem legalizacji pracy i pobytu. Są ważne dla prawie każdego obcokrajowca i w ich przypadku łatwiej jest udzielić odpowiedzi wynikającej z własnego doświadczenia. Budzą też wiele wątpliwości, co przedłuża dyskusję. Najmniej dyskutowane są problemy związane z poszukiwaniem pracy i zakwaterowaniem. Informacja zwykle jest tu konkretna i nie wymaga dyskusji, a tylko prywatnego kontaktu. Każda z omawianych stron ma swojego moderatora, który dba o to, aby podawane informacje były zgodne z celem utworzenia grupy, a także nie zawierały materiałów obraźliwych lub komercyjnych.

Jak wcześniej nadmieniono, w toku analizy wyodrębniono pięć podstawowych typów informacji poszukiwanych przez imigrantów. Poniżej znajduje się ich krótkie omówienie.

Informacje związane z przepisami prawnymi i dokumentami. Przeprowadzone badanie wskazało, iż najczęściej poruszanymi tematami z tego zakresu są kwestie legalizacji pobytu i/lub pracy w Polsce, pytania o to, jak ubiegać się o tymczasową rejestrację konsularną, jak przygotować się do rozmowy z konsulem na temat uzyskania dokumentów na pobyt tymczasowy lub stały, jak zachować się, jeśli wydanie dokumentów zostanie odroczone lub nie ma o nich informacji. Jedna z najczęściej poruszanych kwestii dotyczy szczegółowych aktów prawnych oraz zmian w polskim ustawodawstwie, przede wszystkim związanych z uzyskiwaniem zezwoleń na pobyt czasowy lub stały i dotyczących zatrudniania cudzoziemców, ale też uznania dokumentów, nostryfikacji dyplomów etc. Pełnoprawne wejście w tkankę społeczną kraju przyjmującego wymaga znajomości przepisów prawa umożliwiających legalizację pobytu i ochronę prawną imigranta, bez których trudno mówić o rekonstrukcji utraconego kapitału i sukcesie migracyjnym.

Informacje związane z zakwaterowaniem. Najczęściej publikowanymi postami z tego zakresu są ogłoszenia o poszukiwaniu mieszkania do wynajęcia i - rzadziej - oferty najmu. Można tam również dowiedzieć się o warunkach podpisania umowy przejściowej na wynajem mieszkania (tzw. umowy najmu okazjonalnego) lub gdzie się zwracać, jeśli występują problemy z kaucją albo czynszem. Decyzje podejmowane w obrębie tej kategorii skutkują odmiennymi ścieżkami budowania kapitału społecznego - podtrzymaniem silnej więzi z własną grupą narodową (wybór zakwaterowania w otoczeniu imigrantów) lub większą integracją ze społeczeństwem przyjmującym (mieszkanie poza grupą).

Informacje związane z korzystaniem z usług. Facebook zawiera bardzo dużo informacji na temat rynku usług dla społeczności ukraińskiej w Warszawie i Polsce. Jak pokazały wyniki analizy, praktycznie co druga lub trzecia wiadomość dotyczy możliwości korzystania np. z usług przewozu, fryzjerstwa i usług związanych z urodą. Ponadto do najczęściej zadawanych pytań dotyczących usług należą pytania o usługi 
szkoleniowe i edukacyjne (uzyskanie uprawnień kierowcy, certyfikatu znajomości języka), a także o usługi tłumaczeniowe i potwierdzania dokumentów. Ponadto publikowane są pytania i ogłoszenia dotyczące świadczenia usług w zakresie napraw pomieszczeń, samochodów, fotografowania itp. Często deklarowane jest zapotrzebowanie na usługi korepetytorskie. Najczęściej są one płatne, a osoby, które je oferują, mają na celu dotarcie do nowych klientów i środowisk stanowiących ich naturalną bazę. Migranci oferujący swoje usługi w tym zakresie to osoby żyjące w Polsce od kilku lat, zaznajomione z realiami życia w nowym kraju i znające lokalne rynki, albo też osoby świeżo po przyjeździe, próbujące odbudować grupę klientów na usługi, jakie świadczyli dotąd na Ukrainie (np. transportowe, fryzjerskie i związane z urodą). Zawartość tej kategorii tematycznej wskazuje na silną potrzebę odbudowania utraconego kapitału ludzkiego (kompetencje, certyfikaty) przez migrantów. Rekonstrukcja kapitału społecznego odbywa się przede wszystkim w ramach środowiska samych Ukraińców, z których ci bardziej zadomowieni oferują usługi wspierające nowo przybyłych, a im samym dające miejsce pracy.

Informacje związane z poszukiwaniem pracy. Wyniki badania wskazują na fakt, iż tematyka zatrudnienia jest niezmiennie aktualna dla ukraińskich migrantów jako główny cel ich przyjazdu i jest widoczna na każdej z analizowanych stron. Najczęściej pojawiającymi się postami są te dotyczące poszukiwania pracy, a także z drugiej strony - propozycje pracy. Jednocześnie dosyć często zdarzają się pytania o prawa i obowiązki pracownika i pracodawcy, typy zatrudnienia, a także jak wygląda sytuacja pracowników tymczasowych w Polsce i czego oczekiwać na polskim rynku pracy. Ukraińcy pytają także, jak uchronić się przed niesumiennymi chlebodawcami, gdzie zwracać się w wypadkach niewypłacania pensji oraz które umowy stosować w przypadku zatrudnienia do prac sezonowych. Posty wskazują na istniejącą nieufność przybyszów w stosunku do zatrudniających ich Polaków, wynikającą z krążących w środowisku opowieści o trudnościach z pracodawcami. Częściowo są one równoważone przykładami dobrych doświadczeń, jednak w wątkach o omawianej tematyce niewątpliwie uwidacznia się niski poziom zaufania społecznego ukraińskich migrantów do Polaków i na odwrót.

Informacje związane z rozrywką i odpoczynkiem. Co charakterystyczne, wszystkie wytypowane do badania strony specjalizują się także w informacjach o dostępnych w Polsce rozrywkach i możliwościach odpoczynku, a na niektórych z nich jest to wręcz motyw dominujący w dyskusjach. Dla autorów postów - młodego pokolenia migrantów, najbardziej zadomowionego w mediach społecznościowych, jest to najwyraźniej bardzo ważny aspekt pobytu w Polsce, silnie związany z poczuciem dobrostanu. Użytkownicy badanych stron internetowych nie reprezentują już fali migracji skoncentrowanej na pracy i odkładaniu każdego grosza dla rodziny pozostałej w kraju. Młodzi ludzie chcą w nowym kraju żyć w pełni i budować relacje z otoczeniem społecznym. Równocześnie nie tracą związku z krajem, co bardzo ułatwia im Internet. Na analizowanych stronach można także znaleźć obszerne informacje 


\section{SM̂PP}

o bieżących wydarzeniach na Ukrainie, powiadomienia o spotkaniach z przedstawicielami ukraińskiej kultury i polityki, o nadchodzących imprezach i tym podobne. Dominują jednak wątki dotyczące możliwości zabawy i odpoczynku w Warszawie i całej Polsce.

Drugim etapem działań było przeprowadzenie w kwietniu 2019 roku pięciu częściowo ustrukturyzowanych, pogłębionych wywiadów eksperckich, a następnie analiza ich treści. Wszyscy respondenci byli Ukraińcami co najmniej od 3 lat aktywnymi na polskim rynku pracy, zaangażowanymi we wspieranie zawodowe imigrantów ukraińskich lub bezpośrednio w działania rekruterskie. Wszyscy prowadzili swoją działalność poprzez media społecznościowe. Respondenci to: administrator stron Facebook (Ekspert 1); prezydent Fundacji Ukraińskie Centrum Informacyjne (Ekspert 2); IT-Recruiter w jednej z dużych firm rekruterskich (Ekspert 3); student, przedsiębiorca, przedstawiciel internetowej agencji pośrednictwa pracy (Ekspert 4); koordynator projektu "Inkubator Inicjatyw Migrujących" (Ekspert 5). Na podstawie informacji wyłonionych poprzez analizę dokumentów, ułożono listę zagadnień do scenariusza wywiadu. Pozyskany materiał przeanalizowano pod kątem zaprezentowanych poniżej kwestii związanych z obecnością Ukraińców na polskim rynku pracy.

Podstawowe zasady funkcjonowania imigrantów na rynku pracy Polski (prawodawcze, kulturalne, społeczne). Obserwacje ekspertów są zgodne z danymi statystycznymi: w ostatnich latach migracja Ukraińców do Polski znacznie wzrosła, a warianty poszukiwania pracy urozmaiciły się. O ile do niedawna przeważała migracja nisko wykwalifikowanych pracowników sezonowych, to zdaniem respondentów, począwszy od 2014 roku, zaczęła rosnąć wśród migrantów świadomość tego, że chcą pracować i mieszkać w kraju europejskim z pewnymi życiowymi i finansowymi standardami, co spowodowało napływ lepiej wykształconych przybyszów gotowych osiedlić się na stałe lub na dłużej. Polski rynek pracy jest dla nich atrakcyjny, ale ta atrakcyjność często staje się iluzoryczna lub nieosiągalna dla specjalistów, którzy nie znają wszystkich praw rynku lub są nieprzygotowani do funkcjonowania w realiach z nim związanych. Ponadto, jak wskazują badani, część migrantów nie jest zainteresowana budowaniem trwałych relacji z krajem przyjmującym, ani nawet z mniejszością ukraińską, co rozbija spójność grupy i zmniejsza jej kapitał społeczny.

W Warszawie, oprócz migrantów długoterminowych, jest duża ilość ludzi, którzy przyjeżdżają do tego miasta, żeby zarobić pieniądze. To już generuje podwójną migrację. Dlatego Rynek pracy Polski bardzo często jest iluzorycznie atrakcyjny. (Ekspert 2)

Problemy wynikają przede wszystkim z trudności w znalezieniu pracy zgodnej z wykształceniem oraz odpowiadającej ambicjom migranta. Zdaniem ekspertów, o ile inżynierowie nie mają problemu ze znalezieniem pracy, to osobie z humanistycznym wykształceniem jest o wiele trudniej. Polska potrzebuje coraz więcej analityków i pracowników IT, więc dla studentów i pracowników z Ukrainy istnieją 
bardzo dobre perspektywy w tej dziedzinie. Istnieje również bardzo duży popyt na pracowników sektora turystycznego, choć często są to oferty pracy sezonowej. Inni specjaliści są według respondentów mniej poszukiwani, ponieważ rynek nasyca się pracownikami z Polski. W efekcie wysoko wykwalifikowani i wykształceni migranci są zmuszeni do poszukiwania i wykonywania pracy wymagającej niskich kwalifikacji i bardzo często za mniejsze pieniądze. Zdarzają się też sytuacje, kiedy migranci - ze względu na długie oczekiwanie na pozwolenie na pracę - zmuszeni są do podejmowania pracy nielegalnej, tracąc zarówno ochronę prawną przed nieuczciwymi pracodawcami, jak i szansę na budowę kapitału niematerialnego i materialnego na oczekiwanym poziomie.

Możliwości i przeszkody stojące przed ukraińskimi migrantami. Badani podkreślają, że przed migrantami ukraińskimi polski rynek pracy otwiera dostęp do zatrudnienia w całej Unii Europejskiej. Z ich obserwacji wynika, iż przypadku pracowników o średnim i wysokim poziomie kwalifikacji, pracodawcy chętnie pomagają kandydatom w załatwieniu dokumentów związanych z zatrudnieniem, dostarczają wszystkich niezbędnych informacji. Dzieje się tak, kiedy pracodawcy rzeczywiście zależy na konkretnym specjaliście. W takich warunkach proces uzyskiwania wszystkich dokumentów przebiega sprawnie i zgodnie z prawem. Natomiast, zdaniem ekspertów, jeśli dana osoba podejmuje pracę słabo opłacaną, która nie wymaga kwalifikacji, mogą się pojawić różne problemy - od tych wynikających z nieznajomości własnych praw i obowiązków, po niechęć pracodawcy do podejmowania jakichkolwiek procedur zatrudnienia (dlatego, że nie widzi takiej potrzeby, ale także dlatego, że nie wie, jak to zrobić). Tutaj ukraińscy migranci potrzebują zarówno pomocy, jak i wiedzy o organizacjach, do których można zwrócić się o wsparcie.

Główną spośród fundacji, które pracują, by pomóc ukraińskim migrantom w Polsce, jest fundacja "Nasz wybór", która znajduje się w Warszawie w Ukraińskim domu. W Krakowie działa fundacja „UkrWork”, Fundacja Ukraińskie Centrum Informacyjne, która zajmuje się realizacją projektu „Punkt informacyjny na rynku pracy dla cudzoziemców”. Ta fundacja pomaga nie tylko w kwestiach prawnych, ale także w różnych kwestiach społecznych lub kulturowych. (Ekspert 4)

O sukcesie imigranta w wejściu na rynek pracy decydują zatem nie tylko jego kompetencje zawodowe, ale też jakość relacji społecznych, które jest w stanie nawiązać. Duże wsparcie w tym zakresie oferują liczne fundacje i organizacje imigranckie, kładące bardzo duży nacisk na funkcjonowanie w Internecie i mediach społecznościowych. Daje to możliwość szerokiego dotarcia do potrzebujących wsparcia migrantów bez konieczności kosztownego zakładania filii organizacji w wielu miejscach kraju. Kwestię tę podkreślają w sposób szczególny eksperci związani z organizacjami pozarządowymi (Ekspert 2 i 5).

Warto zwrócić także uwagę na sytuację ludzi przybywających do Polski w celu 166 zdobycia wykształcenia. Zdaniem ekspertów dla studentów szczególną zaletą jest 


\section{SM̂PP}

fakt, iż otrzymują edukację na europejskim poziomie, uczą się języków, poznają realia kraju i w ten sposób ułatwiają sobie dostęp do rynku pracy.

Atrakcyjność polega na tym, że można zdobyć wykształcenie nie droższe, niż na Ukrainie, z dyplomem standardu europejskiego. (Ekspert 1)

Aby odnieść sukces na polskim rynku pracy, potrzebna jest według badanych doskonała znajomość języka polskiego, a także najlepiej angielskiego, a nawet dodatkowo innego.

Możliwość znalezienia pracy zależy od sektora, od zakresu i kompetencji człowieka. Ale w pierwszej kolejności wszystko zależy od języka polskiego. (Ekspert 3)

Jak podkreślają rozmówcy, trzeba także dobrze rozumieć swoje prawa i specyfikę polskiego życia społecznego - jest wtedy o wiele bardziej prawdopodobne, że imigrant dostanie pracę, na którą zasługuje i o którą się stara. To także problematyka bardzo często poruszana w postach migrantów, co wskazuje na świadomość znaczenia wymienionych kwestii dla osiągnięcia sukcesu zawodowego i odbudowania kapitału społecznego w nowym miejscu zamieszkania.

Dla Ukraińców główną przeszkodą w wejściu na polski rynek pracy jest, zdaniem ekspertów, legalizacja dokumentów. Europejczycy z krajów należących do Unii nie mają takich problemów, ponieważ mają automatycznie przyznane prawo do pobytu. Legalizacja pobytu w Polsce jest równa dostępowi do rynku pracy, co powoduje, że każdy wniosek wizowy jest dokładnie weryfikowany. Warto zaakcentować, że dosyć często problemy z dokumentami pojawiają się jeszcze na Ukrainie, kiedy migranci zgadzają się na zakup prawa do pracy lub pobytu za pośrednictwem pośredników lub niezweryfikowanych osób. Korzystanie z usług czarnego rynku okazuje się jednak strategią krótkoterminową i ostatecznie utrudniającą migrantowi odnalezienie się w nowej rzeczywistości.

Często takie dokumenty kupuje się tylko po to, żeby przyjechać do Polski, ale to niedobra droga, ponieważ kiedy idziesz do prawdziwej pracy, stare dokumenty przeszkadzają wyprodukować nowe, legalne. (Ekspert 2)

Skazuje to część Ukraińców na nielegalne zatrudnienie i znacząco utrudnia rozpoczęcie życia w nowym miejscu. Czarny rynek dokumentów wjazdowych to równocześnie, jak podkreślają badani, obszar, w którym dobitnie ujawniają się zagrożenia związane z korzystaniem z nowych mediów. Handel pozwoleniami kwitnie na stronach internetowych. Organizacje pozarządowe starają się przeciwdziałać temu zjawisku, organizując akcje informacyjne w swoich mediach (Ekspert 2, Ekspert 5).

Wiedza, umiejętności, dostęp do informacji, a więc istotne składowe kapitału niematerialnego człowieka, to zdaniem respondentów warunki niezbędne dla sukcesu w samorealizacji na rynku pracy w Polsce. Eksperci zauważają, że aby 
uniknąć problemów, z którymi zderzają się Ukraińcy, konieczne jest uczenie się języka, umiejętność czytania regulaminów i prawa, a w konsekwencji - znajomość przepisów o prawach i obowiązkach osoby pracującej i przebywającej w Polsce. Według nich to jednak nie wystarczy - należy wyraźnie uświadamiać migrantom, że muszą podnosić poziom świadomości obywatelskiej, integrować się z Polakami, ale też, jak uczy doświadczenie, zawsze patrzeć, co się podpisuje oraz komunikować się tylko ze sprawdzonymi pośrednikami. Na razie, mimo rosnącej liczby programów i kursów informacyjnych dotyczących zatrudnienia i jego legalizacji w Polsce, poziom ten wciąż należy uznać za niedostateczny. W czasie rozmów kwalifikacyjnych zasadniczo dominują pytania o umowę o pracę i warunki wynagrodzenia. Praktycznie nikt nie pyta o swoje prawa i możliwości takie jak urlop, ubezpieczenie lub zwolnienie lekarskie:

O takie rzeczy to bardzo mało osób pyta, ponieważ rozumieją, że pracują na prostych pracach, które nie wymagają wysokich kwalifikacji i wysokiej wiedzy. Z tego powodu uważają, że nie mogą pretendować do swoich bazowych praw. Chociaż tak nie jest, to jest obowiązkiem pracodawcy. (Ekspert 4)

Zdaniem ekspertów, w hierarchii wiedzy i umiejętności niezbędnych dla samorealizacji obcokrajowca, na pierwszym miejscu znajdują się języki - wśród nich oczywiście, polski, angielski oraz najlepiej jakiś czwarty język. Cenione są również niektóre składowe kapitału społecznego - to, czy migrant potrafi się odnaleźć w środowiskach międzynarodowych, obcych kulturowo i jak szybko potrafi się adaptować do nowych warunków. Według badanych ważna jest także wiedza o organizacjach obywatelskich, w których można uzyskać informacje o własnych prawach i obowiązkach, a także o instytucjach państwowych, w których w razie potrzeby można szukać pomocy. Najważniejszy i najobszerniejszy zakres niezbędnej wiedzy dotyczy procedur związanych z dokumentami. Jak działać krok po kroku, które dokumenty są potrzebne do zatrudnienia, otrzymania karty pobytu, co daje karta Polaka, co daje reżim bezwizowy - to kwestie kluczowe dla przybysza z zagranicy, pragnącego osiedlić się i podjąć pracę w Polsce. Migranci potrzebują również ogólnej informacji na temat rynku pracy we wszystkich sektorach, wiedzy, gdzie znajduje się największe bezrobocie, gdzie jest największe zapotrzebowanie na specjalistów. Warto także być zorientowanym odnośnie do obowiązków i kompetencji dotyczących określonych rodzajów pracy, szukać opowieści o doświadczeniach osób pracujących w tych zawodach. Niezmiernie ważna jest także integracja społeczna. Jak podkreśla jedna z respondentek,

Jeśli jesteś studentem - to pierwszoplanowo integracja, jak i do ukraińskiego środowiska, tak i do polskiego. Angażować się do aktywności w uniwersytecie. Jeśli jest to emigrant, zacząć od rozumienia swoich praw, możliwości dla siebie i rodzin. Trzeba to zrozumieć i dlatego trzeba czytać książki, chodzić na seminaria od fundacji i miejscowej władzy, akurat po to, żeby polepszać swoją wiedzę. Dalej już rozwijać się osobiście i fachowo w warunkach danego społeczeństwa i zawodu. (Ekspert 5) 


\section{SM̂PP}

Znakomitym poligonem pozwalającym ograniczyć lęk przed zanurzeniem się w obcą kulturę jest zdaniem respondentów Internet i media społecznościowe. Nawiązywanie wirtualnych kontaktów z lokalnymi grupami tematycznymi (organizacje studenckie, hobbyści etc.) stanowić może pierwszy krok do "miękkiego" wejścia w nową społeczność (Ekspert 2, Ekspert 4). To znaczenie Internetu w budowaniu tożsamości człowieka w warunkach migracji podkreśla wielu badaczy, m.in. Michela Nedelcu, pisząca wręcz o zwrocie kosmopolitycznym w badaniach nad migracjami, zapoczątkowanym przez nowe technologie. Zdaniem Nedelcu migrant zaczyna funkcjonować w rzeczywistości zawieszonej pomiędzy "tu” i „tam”, łącząc je w nową przestrzeń ukształtowaną wedle jego potrzeb. Badaczka pisze:

Wielu migrantów łatwo przemieszcza się w międzynarodowych przestrzeniach społecznych tworząc nowe konfiguracje społeczne, nowe geograficzne obszary społeczne i polityczne. W ten sposób migranci online ucieleśniają wiele zawiłości wynikających z procesów kosmopolityzacji połączonych w ten sposób światów społecznych: przestrzenie przynależności, wielobiegunowe systemy odniesień, lojalności i identyfikacji, coraz bardziej złożone systemy obywatelstwa, wzajemnie powiązane style życia oraz zdolność do działania na odległość w czasie rzeczywistym. (Nedelcu 2012, 1341)

Sposoby poszukiwania pracy przez ukraińskich migrantów. Ważnym miejscem dla poszukujących pracy ukraińskich migrantów jest urząd pracy, który uchodzi za źródło bezpiecznych ofert. Poszukujący pracy wymagającej wyższych kwalifikacji korzystają z LinkedIn. Pomocą służą także fundacje - prośby o pomoc w znalezieniu zatrudnienia stanowią obecnie od 75 do $80 \%$ wszystkich kierowanych do nich wniosków. Głównym źródłem poszukiwań jest jednak obecnie Internet, z dominującą rolą Facebooka. Zdaniem ekspertów zauważalna staje się niepokojąca tendencja w działalności przedsiębiorców ukraińskich w Polsce. Ukraińcy często próbują organizować agencje pracy dla Ukraińców lub organizować takie obszary, w których pracują tylko pracownicy ukraińscy. Tym samym zamykają się oni na sztucznie stworzonym ukraińskim rynku pracy w Polsce i nie integrują się z polskim środowiskiem biznesowym ani społecznym. Jest to tendencja powszechnie obserwowana w środowiskach imigracyjnych, jednak działająca na dłuższą metę na szkodę migrantów, utrudniając proces rekonstrukcji kapitału społecznego w nowych warunkach (Breton 1964; Leonowicz-Bukała 2013; Brzozowska 2018; Grabowska-Lusińska, Jaźwińska 2012). W przypadku studentów sytuacja wygląda inaczej - chętnie korzystają oni ze staży czy podejmują gorzej płatne prace, traktując je jako etapy prowadzące na kolejne szczeble drabiny zawodowej. Jak wskazują eksperci, młodzi ludzie wiążący swoją karierę z Polską muszą podnosić kompetencje, by stać się liderami w zakresie swojej specjalizacji (Ekspert 1, 3, 4).

Polscy pracodawcy są otwarci na zatrudnianie ukraińskich pracowników, choć oferują zróżnicowane wsparcie. Według ekspertów związanych z rynkiem pracy w Polsce (współpracujących z dużymi firmami), korporacje i duże firmy są bardziej otwarte 
na pomoc w procesie zatrudnienia i dostarczają niezbędnych informacji, oferują też zwykle wszelkie wsparcie socjalne, a nawet kulturowe. Natomiast w nisko opłacanych pracach zdarzają się zarówno pozytywne przykłady, jak i nieuczciwi pracodawcy, przed którymi ukraińscy migranci często nie są chronieni, ponieważ nie obejmuje ich ochrona prawna lub nie posiadają na ten temat wiedzy (Ekspert 3, 4). Jakkolwiek pozycja zawodowa ekspertów mogła wpłynąć na taką ocenę, jest to prawidłowość widoczna także w innych badaniach polskich i międzynarodowych (World Bank 2019, Andrejuk 2017, Adamczyk 2018).

\section{Podsumowanie}

Głównym celem badań zaprezentowanych w artykule była identyfikacja wątków tematycznych najobficiej reprezentowanych w facebookowych dyskusjach migrantów ukraińskich w Polsce, wychwycenie ich specyfiki, a także ocena roli, jaką media społecznościowe i Internet odgrywają w procesie rekonstrukcji kapitału społecznego migrantów z Ukrainy w nowym miejscu pobytu. Materiał uzyskany poprzez analizę pięciu najpopularniejszych wątków, gromadzących na Facebooku imigrantów z Ukrainy, uzupełniono o treść wywiadów z pięcioma ekspertami - ukraińskimi ekspatami wykorzystującymi Internet do prowadzenia działalności zawodowej, doradczej i integracyjno-kulturalnej dla imigracji, którą reprezentują.

W toku badań wyłoniono 5 typów informacji, jakich użytkownicy analizowanych stron poszukują w sieci: dokumenty i przepisy prawne; zakwaterowanie; poszukiwanie pracy; usługi; rozrywka i odpoczynek. Analiza zarówno informacji poszukiwanych przez ukraińskich imigrantów w sieci, jak i opinii ekspertów, wskazuje na istotne znaczenie rekonstrukcji kapitału niematerialnego migrantów ukraińskich wchodzących na polski rynek pracy. Obok kapitału ludzkiego, intuicyjnie otaczanego troską w pierwszej kolejności (poszukiwanie informacji na temat możliwości potwierdzania kompetencji certyfikatami, dokumentów legalizujących pobyt i umożliwiających podjęcie pracy jako dominujące w dyskusjach wątki), znaczącą rolę odgrywa także kapitał społeczny, bez którego odbudowania trudno o sukces migracyjny, czego przybysze z Ukrainy publikujący posty na analizowanych stronach zdają się mieć świadomość. Ukraińcy, piszący na stronach Facebooka, stosują dwie podstawowe, szeroko opisane w literaturze (Breton 1964; Hiller, Franz 2004; Siuda 2008; Brzozowska 2018; Grabowska-Lusińska, Jaźwińska 2012; Leonowicz-Bukała 2013) strategie odbudowy podstaw tego kapitału. Pierwsza, to szukanie intensywnego kontaktu z własnym kręgiem kulturowym, zatrudnianie się u ukraińskich pracodawców lub oferowanie usług innym migrantom, a także wybieranie miejsca zamieszkania w sąsiedztwie Ukraińców. Strategia ta zamyka ich na sztucznie stworzonym ukraińskim rynku pracy w Polsce i utrudnia integrację ze społeczeństwem kraju przyjmującego. Strategia druga wiąże się z wejściem w tkankę społeczną kraju przyjmującego, poszukiwaniem 


\section{SM̂PP}

pracy i mieszkania w otoczeniu Polaków, integracją z polskim środowiskiem m.in. poprzez uczestniczenie w życiu kulturalnym kraju. Jak wskazują eksperci, pierwszą strategię wybierają osoby z niższym lub nie do wykorzystania na polskim rynku pracy wykształceniem, mentalnie silnie związane z ojczyzną, które nie myślą o trwałej migracji, zaś drugą preferują osoby młode, studiujące lub z wyższym wykształceniem, biegłe w korzystaniu z nowych technologii, choć - co ważne - także i one starają się podtrzymywać więzi z krajem pochodzenia. Chęć ta z jednej strony, a gotowość uczestniczenia w życiu kraju przyjmującego z drugiej - świadczą o kształtowaniu modelu świadomego migranta, który kreuje nową tożsamość, sprawnie korzystając z nowych mediów, wykorzystywanych przez niego do podtrzymywania starych i budowania nowych więzi społecznych.

Wyniki badań wskazują jednak także na konieczność gruntownego przygotowywania migrantów do wejścia na polski rynek pracy, obejmującego zarówno kwestie organizacyjne, jak i głębsze zagadnienia prawne oraz znajomość uwarunkowań społeczno-kulturowych (należy podkreślić, że część problemów, z jakimi borykają się ukraińscy migranci, jest nieobca także Polakom wchodzącym na rynek pracy, jednak precyzyjna ocena specyfiki sytuacji Ukraińców wymagałaby odrębnych analiz). Dopiero kompleksowe podejście do tych zagadnień da szansę na skuteczną integrację społeczną, ze strony migranta wymaga jednak podjęcia dużego wysiłku samokształcenia, związanego z poszukiwaniem informacji w różnych źródłach, głównie cyfrowych. Wyniki wstępnie wskazują na znaczenie nowych mediów w procesie adaptacji społecznej migrantów (choć zakres ich roli oraz kwestia ewentualnej odmienności sposobów korzystania z Internetu przez migrantów i niemigrantów domaga się odrębnych, pogłębionych badań). Internet, w tym media społecznościowe, stanowią cenne źródło wiedzy na temat informacyjnych potrzeb osób planujących przyjazd do Polski, a zarazem znakomitą platformę do dostarczenia im niezbędnych zasobów edukacyjnych i informacyjnych.

Badania przedstawione w niniejszym artykule stanowią jedynie przyczynek do analizy sytuacji imigrantów ukraińskich w Polsce, ich możliwości w zakresie rekonstrukcji kapitału społecznego, a także roli nowych mediów w procesie integracji społecznej zarówno z Polakami, jak i innymi migrantami ukraińskimi. Analizując wypowiedzi ekspertów należy wziąć pod uwagę, że wszyscy należą do środowiska osób z wyższym wykształceniem lub będących w trakcie jego zdobywania, bardzo sprawnie poruszających się w środowisku cyfrowym i dobrze znających język kraju przyjmującego. Z kolei migranci, z którymi mają oni kontakt poprzez media społecznościowe, to również osoby posiadające pewne kompetencje medialne. Wycinek rzeczywistości, którego obraz wyłania się z wypowiedzi ekspertów, jest więc zaledwie fragmentem nieobejmującym tej części imigrantów, która dysponuje ograniczonymi kompetencjami w zakresie korzystania z mediów cyfrowych. Problem podziału cyfrowego ( $d i-$ gital divide), z którym mamy tu do czynienia, leży u podstaw niereprezentatywności każdych badań prowadzonych w Internecie, których przedmiotem nie są wyłącznie 
internauci. Nierówny dostęp do technologii nie jest jednak jedynie kłopotem metodologicznym badaczy - o wiele poważniejsze są jego konsekwencje społeczne. Prowadzi bowiem do coraz głębszego wykluczenia społecznego i ekonomicznego (Brzozowska 2018: 74). Migranci pozbawieni dostępu do Internetu mają ograniczony kontakt zarówno ze wspólnotą, którą zostawili w kraju pochodzenia, jak i z nową diasporą, a także formalnymi i nieformalnymi źródłami informacji. Media społecznościowe pełnią zatem coraz istotniejszą, inkluzyjną rolę w procesie odtwarzania kapitału społecznego imigrantów i jako takie wymagają zarówno uwagi ze strony badaczy, jak i szerszych działań niwelujących wykluczenie cyfrowe.

\section{Bibliografia}

Adamczyk A. (2018), Imigracja zarobkowa do Polski. Casus Ukraińców (2014-2017), „Środkowoeuropejskie Studia Polityczne", 2, s. 115-135. DOI 10.14746/ssp.2018.2.8.

Andrejuk K. (2017), Self-employed migrants from EU Member States in Poland: differentiated professional trajectories and explanations of entrepreneurial success, "Journal of Ethnic and Migration Studies", February 2017, vol. 43(4), p. 560-57, DOI: 10.1080/1369183X.2016. 1249050.

Bauman Z. (2000), Globalizacja, Warszawa: Państwowy Instytut Wydawniczy.

Bauman Z. (2006a), Płynna nowoczesność, Kraków: Wydawnictwo Literackie.

Bauman Z. (2006b), Praca, konsumpcjonizm i nowi ubodzy. Kraków: Wydawnictwo WAM.

Beck U. (2004), Społeczeństwo ryzyka. W drodze do innej nowoczesności, Warszawa: Wydawnictwo Naukowe "Scholar".

Bourdieu P., Passeron J.P. (2012), Reprodukcja, Warszawa: Wydawnictwo Naukowe PWN.

Breton R. (1964), Institutional Completeness of Ethnic Communities and Personal Relations of Immigrants, "The American Journal of Sociology", 70, 2.

Brzozowska A. (2018), Społeczne zakotwiczenie w klasowo-etnicznych formach tożsamości a integracja polskich i ukraińskich migrantów, "Studia Migracyjne - Przegląd Polonijny", 1, s. 69-99.

Castells M. (2003), Galaktyka Internetu: Refleksje nad Internetem, biznesem i społeczeństwem, Poznań: Rebis.

CBOS (2018a), O nieufności i zaufaniu, Komunikat z badań nr 35/2018, Warszawa: Fundacja Centrum Badania Opinii Społecznej. Źródło: https://www.cbos.pl/SPISKOM.POL/2018/K_035_18. PDF [data dostępu: 20.12.2018].

CBOS (2018b), Stosunek Polaków i Czechów do przyjmowania uchodźców, Komunikat z badań nr 87/2018, Warszawa: Fundacja Centrum Badania Opinii Społecznej. Źródło: https://www. cbos.pl/SPISKOM.POL/2018/K_087_18.PDF [data dostępu: 26.07.2019];

Chapman A. (2018), Filling Poland's labour gap. Źródło: https://poland-today.pl/filling-polands-labour-gap/ [data dostępu: 20.12.2018].

Chiswick B.R, Lee Y.L. (2005), A Longitudinal Analysis of Immigrant Occupational Mobility: A Test of the Immigrant Assimilation Hypothesis, "International Migration Review”, vol. 39, Issue 2, p. 332-353.

Czapiński J. (2008), Kapitał ludzki i kapitał społeczny a dobrobyt materialny. Polski paradoks, „Zarządzanie Publiczne”, 2(4), 2008, s. 5-27. 


\section{SM̂PP}

Dekker R., Engbersen G. (2014), How social media transform migrant networks and facilitate migration, "Global Networks" 14, 4, p. 401-41

Dijk van J. (2010), Społeczne aspekty nowych mediów, Warszawa: Wydawnictwo Naukowe PWN.

Giddens A. (2006), Nowoczesność i tożsamość. „Ja” i społeczeństwo w epoce późnej nowoczesności, Warszawa: Wydawnictwo Naukowe PWN.

GUS (2019), Popyt na pracę w I/ kwartale 2019 r., Źródło: https://stat.gov.pl/obszary-tematyczne/ rynek-pracy/popyt-na-prace/popyt-na-prace-w-drugim-kwartale-2019-roku,2,34.html [data dostępu: 28.01.2020].

Hiller H.H., Franz T.M. (2004), New ties, old ties: the use of the internet in diaspora, "New Media and Society", No. 6, p. 731-752, https://doi.org/10.1177/146144804044327

Leonowicz-Bukała I. (2013), E-migracja 2.0. Internet jako przedmiot badań migracyjnych, „Komunikacja Społeczna" 2013, nr 3(7).

Golinowska S., Marek E. (1994), Procesy migracji zagranicznych w Polsce, w: S. Golinowska, E. Marek (red.), Studia o procesach migracji zagranicznych, t. 1, Charakterystyka procesów migracyjnych, Studia i Materiały, z. 3, Warszawa: Instytut Pracy i Spraw Socjalnych.

Górny A., Kaczmarczyk P. (2003), Uwarunkowania i mechanizmy migracji zarobkowych w świetle wybranych koncepcji teoretycznych, „Prace Migracyjne”, 49, Ośrodek Badań nad Migracjami, Instytut Studiów Społecznych UW.

Grabowska-Lusińska I., Jaźwińska E. (2012), Mobilność przestrzenna, społeczna i kariery zawodowe migrantów: cele, problemy i podejścia badawcze na podstawie badań OBM UW, „Studia Migracyjne - Przegląd Polonijny", 2, s. 71-103.

GUS (2011), Mały Rocznik Statystyczny Polski, Warszawa: Główny Urząd Statystyczny.

Jaroszewicz M. (2018), Migracje z Ukrainy do Polski. Stabilizacja trendu, Warszawa: Ośrodek Studiów Wschodnich im. Marka Karpia, Źródło: https://www.osw.waw.pl/sites/default/files/ Raport_PL_Migracje-z-Ukrainy_net.pdf [data dostępu: 30.01.2020].

Jeannet A.-M., Ademmer E., Ruhs M., Stöhr T. (2019), What asylum and refugee policies do Europeans want? Evidence from a cross-national conjoint experiment, "EUI Working Papers" 73, Robert Schuman Centre for Advanced Studies. Źródło: https://cadmus.eui.eu/bitstream/handle/1814/64384/RSCAS_2019_73.pdf? sequence=4\&isAllowed=y [data dostępu: 21.01.2020].

Jóźwiak I., Piechowska M. (2017), Crisis-driven Mobility between Ukraine and Poland. What Does the Available Data (Not) Tell Us, CMR Working Papers, Źródło: http://www.migracje.uw.edu. pl/wp-content/uploads/2017/05/WP99157.pdf [data dostępu: 28.01.2020].

Kaczmarczyk P., Tyrowicz J. (2008), Migracje osób z wysokimi kwalifikacjami, Warszawa: Fundacja Inicjatyw Społeczno-Ekonomicznych, Źródło: http://www.klon.org.pl/files/1 bezrobocie.org.pl/ public/biuletyny_fise/biuletyn_fise_nr4_kwalifikowani.pdf [data dostępu: 16.01.2020].

Kindler M., Wójcikowska-Baniak K. (2019), (Missing) Bridging Ties and Social Cap-ital? The Creation and Reproduction of Migrants' Social Network Advantages: The Case of Ukrainian Migrants in Poland. "Central and Eastern European Migration Review", 8(1), p. 95-116.

Kwieciński Z. (1991), Edukacja jako wartość odzyskiwana wspólnie. (Głos w dyskusji o uspołecznieniu szkoły), „Edukacja”, nr 1, s. 89.

Leszkowicz-Baczyński L., Ewolucja przekonań Polaków wobec „obcych” jako efekt kryzysu migracyjnego w Europie, "Colloquium Wydziału Nauk Humanistycznych i Społecznych”, 2, 2018. Levinson P. (2010), Nowe nowe media, Kraków: Wydawnictwo WAM.

Manovich L. (2011), Język nowych mediów, Warszawa: Łośgraf. 
Milewski M., Ruszczak-Żbikowska J. (2008), Motywacje do wyjazdu, praca, więzi społeczne i plany na przyszłość polskich emigrantów przebywających w Wielkiej Brytanii i Irlandii, „CMR Working Papers" 35/93, Seria: Prace Migracyjne, Centre of Migration Research. Źródło: http:// www.migracje.uw.edu.pl/publ/610 [dostep: 28.01.2020].

NBP (2018), Obywatele Ukrainy pracujący w Polsce. Raport z badania, Warszawa: Narodowy Bank Polski, Źródło: https://www.nbp.pl/aktualnosci/wiadomosci_2018/obywateleUkrainypracujacywPolsceraport.pdf [data dostępu: 18.01.2020].

Navarrete C., Huerta E. (2006), Building Virtual Bridges to Home: The Use of the Internet by Transnational Communities of Immigrants "International Journal of Communications Law \& Policy", Special Issue, Virtual Communities, Autumn. Żródło: https://ssrn.com/abstract=1683606 [data dostępu: 18.01.2020].

Nedelcu M. (2012), Migrants' New Transnational Habitus: Rethinking Migration Through a Cosmopolitan Lens in the Digital Age, „Journal of Ethnic and Migration Studies” 38, 9, p. 1339$-1356$.

OECD (2018), International Migration Outlook 2018, Źródło: https://read.oecdilibrary.org/socialissuesmigrationhealth/internationalmigrationoutlook2018_migr_outlook2018en\#page1 [data dostępu: 15.01.2020].

Piontkivska I., Jablonovsky D., Ruda Y. (2018), How many Ukrainians have departed and what can be done about this? Kyiv: Center for Economic Strategy, Źródło: https://ces.org.ua/en/ how-many-ukrainians-have-departed-and-what-can-be-done-about-this-2/ [data dostępu: 28.01.2020].

Putnam R.D. (2003), Better together. Restoring the American community, New York: Simon \& Schuster.

Reeskens T., Hooghe M. (2008), Cross-cultural measurement equivalence of generalized trust. Evidence from the European Social Survey (2002 and 2004), "Social Indicators Research" 85(3), DOI: 10.1007/s11205-007-9100-z

Simmel G. (2005), Obcy, w: P. Sztompka, M. Kucia (red.), Socjologia. Lektury, Kraków: Wydawnictwo Znak.

Siuda P. (2008), Wirtualna komunikacja z własnym narodem, czyli rola Internetu w podtrzymywaniu tożsamości narodowej emigrantów, w: M. Wawrzak-Chodaczek (red.), Komunikacja społeczna w świecie wirtualnym, Toruń: Wydawnictwo Adam Marszałek.

Spyratos S., Vespe M., Natale F., Ingmar W., Zagheni E., Rango M. (2018), Migration Data using Social Media: a European Perspective, Publications Office of the European Union, Luxembourg, doi:10.2760/96428

Sztompka P. (2016), Kapitał społeczny. Teoria przestrzeni międzyludzkiej, Kraków: Wydawnictwo Znak.

Urząd do Spraw Cudzoziemców (2019), Raport na temat obywateli Ukrainy, Źródło: https:// udsc.gov.pl/statystyki/raporty-specjalne/biezaca-sytuacja-dotyczaca-ukrainy/ [data dostępu: 28.01.2020].

WhySocial (2019), Użytkownicy social media w Polsce i na świecie, Żródło: https://www.whysosocial.pl/uzytkownicy-social-media-w-polsce-i-na-swiecie/ [data dostępu: 28.01.2020].

World Bank (2019), Migration and Brain Drain, Washington: The World Bank Publications, DOI: 10.1596/978-1-4648-1506-5

Znaniecki F., Thomas W. (1976), Chłop polski w Europie i Ameryce, T. V, Warszawa: Ludowa Spółdzielnia Wydawnicza. 
ZUS (2019), Cudzoziemcy w polskim systemie ubezpieczeń społecznych, Źródło: https://www. zus.pl/documents/10182/2322024/Cudzoziemcy+w+ polskim + systemie + ubezpiecze\%C5 \%84+spo\%C5\%82ecznych.pdf/4498fca6-981d-a37c-3742-8e4e74e20a32 [data dostępu: 28.01.2020].

Випускники яких спечіальностей частіше шукають роботу. Work.ua. Źródło: https://www.work. ua/news/ukraine/1004/ [data dostępu: 20.12.2018 r.].

Мостова Ю., Рахманін С. (2018), залишаються найбільш уперті, інертні й старі. Źródło: https://gordonua.com/ukr/publications/zalishayutsya-nayupertsh-nayblsh-nertn-star-dzerkalotizhnya-kms-zyasuvali-prichini-masovogo-vdzdu-ukrancv-za-kordon-229094.html [data dostępu: 10.01.2019 r.].

Кулицький С. (2017). Проблеми розвитку ринку праці в Україні. Україна: події, факти, коментарі. - 2017. Źródło: http://nbuviap.gov.ua/index.php?option=com_content\&view= article\&id=3188:rinok-pratsi-v-ukrajini\&catid=8\&ltemid=350. [data dostępu: 20.12.2018 r.].

Лібанова Е. (2018). Інтерв'ю для «Радіо Свобода». Źródło: https://gordonua.com/ukr/news/politics/ libanova-upovilnennja-migratsiji-mozhe-statisja-todi-koli-zarplata-ukrajintsiv-bude-stanoviti70-75-vid-polskogo-rivnja-244129.html [data ddostępu: 15.12.2018 r.].

Пашкіна Т. (2017). Ми випускаємо дипломованих безробітних. Źródło: https://innovationhouse. org.ua/ukrayina/hr-fahivets-tetyana-pashkina-my-vypuskayemo-dyplomovanyh-bezrobitnyh/ [data dostępu: 15.12.2018]. 